\title{
DRUŠTVENO ODGOVORNO POSLOVANJE U KONTEKSTU PONAŠANJA POTROŠAČA PRI KUPNJI PREHRAMBENIH PROIZVODA U REPUBLICI HRVATSKOJ
}

\author{
Romana Zlatar-Vulić
}

\author{
„Podravka“ d.d. \\ Ante Starčevića 32, 48000 Koprivnica \\ e-mail: romana.zlatar@gmail.com
}

\begin{abstract}
Sažetak
Suvremeno poslovanje pred poduzeća postavlja brojne izazove pri ostvarenju definiranih ciljeva i uspješnih poslovnih rezultata, poštujući temeljne društvene i moralne vrijednosti te vodeći brigu o dobrobiti zajednice. Sve veći broj poduzeća, shvaća da je u poslovnu strategiju potrebno ugraditi brigu o društvu i životnoj sredini, što je svojevrsno ulaganje u konkurentsku prednost i postizanje efikasnog poslovanja poduzeća s ciljem poboljšanja dobrobiti društva u cjelini. Uspješna i ugledna poduzeća svoje poslovanje više ne temelje isključivo na stjecanju maksimalne dobiti već u strategije poslovanja uključuju primjenu principa drustveno odgovornog poslovanja (DOP) na dobrovoljnoj osnovi u namjeri uskladivanja poslovanja s potrebama drustva te stvaranja visokih standarda života za interesno utjecajne skupine (dionike) izvan i unutar poduzeća.

Cilj ovoga rada bio je utvrditi postoji li statistički značajna povezanost izmedu spola, dobi i stručne spreme u odnosu na informiranost ispitanika o pojmu DOP-a te utječu li informacije vezane uz provodenje DOP-a poduzeća prehrambenih proizvoda na odluku ispitanika o kupnji njihovih proizvoda. Rezultati istraživanja su pokazali da ne postoji statistički značajna povezanost izmecu spola i dobi s jedne te upoznatosti ispitanikas DOP-om s druge strane. Medutim, utvrdeno je da ona postoji izmecu stručne spreme i upoznatosti ispitanika s pojmom DOP-a (manja je kod ispitanika s nižom stručnom spremom). Istraživanje pokazuje i da ne postoji statistički značajna razlika izmedu dobi i stručne spreme ispitanika u odnosu na zanimanje potrošača za DOP prehrambenih poduzeća, ali postoji sobzirom na njihov spol (veće je kod muškaraca). Takoder je utvrdeno da je kvaliteta odlučujući faktor u procesu odabira i kupnje prehrambenih proizvoda, ali ne postoji statistički značajna razlika izmedu spola, dobi i stručne spreme ispitanika po tom pitanju.
\end{abstract}

Ključne riječi: poduzeće, društveno odgovorno poslovanje, poslovna strategija, održivi razvoj

\section{UVOD}

U promjenjivoj poslovnoj okolini poduzeća moraju biti sposobna djelovati u skladu sa svojom okolinom, promptno reagirajući na promjene uvažavanjem zahtjeva okoline, uz zadržavanje osnovnih načela i vrijednosti, nastojeći ostvariti definirane poslovne ciljeve te dugoročno osigurati konkurentske prednosti ako žele ojačati svoj tržišni položaj. Na putu ostvarenja svojih poduzetničkih pothvata poduzeća definiraju, provode i unaprje- 
đuju taktičke pristupe nastojeći udovoljiti zahtjevima zajednice uključujući se u rješavanje problema povezanih $s$ općom dobrobiti društva i okoliša primjenom koncepta „društveno odgovornog poslovanja“. Na taj način poduzeća nastoje ostvariti koncept društvene odgovornosti te povećati razumijevanje javnosti o svojoj funkciji i poslovnim ciljevima utječući na okruženje u kojemu djeluju.

U ovom radu pristupa se društveno odgovornom poslovanju u kontekstu ponašanja potrošača pri kupnji prehrambenih proizvoda u Republici Hrvatskoj. Cilj je rada utvrditi postoji li statistički značajna povezanost odabranih demografskih karakteristika (spola, dobi i stručne spreme) ispitanika s njihovom informiranosti o pojmu društveno odgovornog poslovanja (DOP). Nadalje, cilj je ustanoviti postoji li statistički značajna razlika u interesu ispitanika o primjeni DOP-a prehrambenih poduzeća, ovisna o spolu, dobi i stručnoj spremi, te utječe li ista na odluku o kupnji proizvoda tih poduzeća. Točnije, konačni je cilj utvrditi je li kvaliteta odlučujući faktor u procesu odabira i kupnje prehrambenih proizvoda te postoje li razlike između ispitanika po tom pitanju bazirane na testiranim demografskim karakteristikama.

\section{TEORIJSKA POZADINA}

\subsection{Pojmovno odredenje drusttveno odgovornog poslovanja}

Poduzeća koja provode aktivnosti društveno odgovornog poslovanja (engl. corporate social responsibility - CSR) obvezuju se na profesionalnu i etičku odgovornost spram dionika ${ }^{1}$ (interesno utjecajnih skupina) čiji razvoj i međusobno interesnu suradnju podupiru i provode. Društveno odgovorno poslovanje (DOP) ima vitalnu ulogu u posredovanju između poslovnog sektora (koji stvara privatna dobra, a time i bogatstvo naroda), državne vlasti (koja vodi brigu o javnim dobrima) i institucija civilnoga društva (obitelji, crkve, nevladinih organizacija i sl.) (Young, 2014).

Europska komisija u svojim „Smjernicama za politiku društvene odgovornosti poduzeća“ iz 2003. definira društveno odgovorno poslovanje kao „koncept prema kojemu poduzeće na dobrovoljnoj osnovi implementira brigu o društvenim pitanjima i zaštiti okoliša u svoje poslovne aktivnosti i odnose s dionicima (vlasnicima, dioničarima, zaposlenicima, potrošačima, dobavljačima, vladom, medijima i širom javnošću)“" (prema Ćorić, 2008). Prema Letici (2010), društvena odgovornost poduzeća je koncept kod kojeg poduzeća dobrovoljno odlučuju pridonositi boljem društvu i čišćem okolišu.

U praksi se spominje izuzetno mnogo definicija i objašnjenja povezanih s terminom „društveno odgovorno poslovanje“, no svima je zajednička činjenica da se radi o dobrovoljnoj praksi i iznadprosječno pozitivnom djelovanju u društvu i prema društvu (Kotler i Lee, 2009). DOP je koncept koji poduzeća primjenjuju uključujući društvene i ekološke probleme u svoje poslovanje i svoju interakciju s dionicima (zaposlenicima,

1 Dionici - „Interesno utjecajne skupine“ koje utječu ili su pod utjecajem odluka i aktivnosti poduzeća (Bačun i sur., 2012) 
kupcima, dioničarima, investitorima, lokalnim zajednicama ili vladom) na dobrovoljnoj osnovi (Crowther i Güler, 2008). Poduzeća koja su se opredijelila za ostvarenja koncepta DOP-a, teže pozitivnom i transparentnom upravljanju, promovirajući interese različitih dionika. Dionici (engl. stakeholders) su pojedinci, grupe ili organizacije koje u procesu ostvarenja ciljeva značajno utječu na djelovanje poduzeća i obratno.

Buble (2009) smatra da društvena odgovornost podrazumijeva obvezu menadžmenta da poduzima akcije koje će doprinijeti dobrobiti i interesima društva i poduzeća. Prema Krkaču (2007) postoji nekoliko vrsta odnosa poduzeća i njegovih dionika - odnos prema vlasnicima, odnos prema zaposlenicima (sigurnost radnog mjesta, pomaganje socijalno ugroženih, sigurnost zaposlenika i sl.), odnos prema kupcima i klijentima (sigurnost proizvoda, zaštita potrošača i sl.), odnos prema okolišu (ekološka osviještenost, očuvanje okoliša) i odnos prema zajednici (pomaganje lokalnoj i / ili široj zajednici). Za razliku od Krkača, Tench i Yeomans (2009) u dionike ubrajaju zaposlenike, ulagače kapitala, kupce, konkurente, širu javnost, dobavljače, lokalnu zajednicu, itd.

Osim pozitivnom djelovanju i utjecaju u zajednici i društvu, društvena odgovornost doprinosi i održivom razvoju. Održivi razvoj (OR) je okvir za oblikovanje politika i strategija kontinuiranog gospodarskog i socijalnog napretka, bez štete za okoliš i prirodne izvore bitne za ljudske djelatnosti u budućnosti (Pavić-Rogošić, 2010). Filozofija OR-a predstavlja ravnotežu između uporabe i očuvanja okoliša kao prirodnog dobra te obnavljanja prirodnih resursa za potrebe budućih generacija. Osnovni cilj OR-a poboljšanje je kvalitete života, kako iz aspekta pojedinca u društvu, tako i iz aspekta poduzeća u djelokrugu njegovog poslovanja. Kvaliteta okoliša bitna je komponenta razvoja današnjih te osiguranja resursa razvoja budućih generacija. Stoga je od izuzetnog značaja da poduzeća što prije prepoznaju potrebu integracije i primjene sustavnih aktivnosti stvaranja dodatnih vrijednosti korištenjem resursa te tehničkog i tehnološkog razvoja koji uzimaju u obzir ekonomske i društvene čimbenike kao i čimbenike povezane sa zaštitom okoliša. Opredjeljenje za društvenu odgovornost postalo je jedna od obveznih, glavnih tema korporativne komunikacije (Kotler i Lee, 2009). DOP ima neupitan utjecaj na razvoj cijelog gospodarstva i društvene svijesti ne narušavajući svoj temeljni cilj - ostvarenje dobiti. Poduzeća prilagođavaju svoje poslovanje potrebama društva u kojem djeluju omogućujući uspješno ostvarenje postavljenih ciljeva. Poslovanje temeljeno na DOP-u poduzećima omogućuje stvaranje uvjeta za: povećanje prodaje i tržǐ̌nih udjela, jačanje komparativnih prednosti i povjerenja, imidža i reputacije, unaprjeđenje kvalitete proizvoda, privlačenje i zadržavanje kvalitetnih kadrova, smanjenje troškova poslovanja, povećanje privlačnosti za investitore i financijske analitičare, unaprjeđenje odnosa sa zajednicom itd. (Carroll i Shabana, 2010).

Osim navedenih pozitivnih aspekata DOP-a u odnosu na poslovanje i ugled poduzeća, postoje i pobornici koji zagovaraju tradicionalni pristup odgovornosti te maksimiziranje dobiti poduzeća. Milton Friedman, jedan od najutjecajnijih ekonomista 20. st., smatrao je da postoji samo jedna odgovornost poslovanja, a to je sudjelovanje u aktivnostima poduzeća poštujući pravila i koristeći se raspoloživim resursima s ciljem povećanja dobiti. Promatrajući povijesni razvoj DOP-a, uočavamo stanovite promjene 60-tih i 70-tih 
godina 20. stoljeća. One se sustavno odvijaju, a nadograđuju se metode i primjene od vremena kada su poduzeća počela shvaćati nužnost povezivanja s internim i eksternim dionicima radi stjecanja uzajamnih koristi. Prema Bagić i sur. (2006), možemo izdvojiti neke od ključnih događaja koji su utjecali na razvoj društveno odgovornog koncepta: počevši od 1972. (Prva svjetska konferencija o zaštiti okoliša u Stockholmu), do početka društveno odgovornog poslovanja kao dijela europske politike sadržanog u Bijeloj knjizi (dokument koji sadržava prijedloge za djelovanje EU u određenom području pod nazivom „Rast, konkurentnost, zapošljavanje - izazovi i načini napretka u 21. stoljeću“ objavljen 1993. od strane Europske komisije o rastu i zapošljavanju) te do 2001. kada Europska komisija objavljuje Zelenu knjigu (dokument kojim potiče raspravu o određenoj temi na europskoj razini, pod nazivom „Promicanje europskog okvira za društveno odgovorno poslovanje“). Nadalje, važno je spomenuti 2006. godinu, kada je objavljena revidirana strategija održivog razvoja EU (Bagić i sur., 2006). Europska komisija 2011. proširuje definiciju DOP-a (Matešić i sur., 2015), a 2013. objavljuje dokument u kojemu naglašava potrebu za transparentnošću poslovanja i nefinancijskog izvješćivanja. Zatim dolazimo do današnjeg društva koje je sve osjetljivije u smislu društvenih ciljeva koje sve veći broj poduzeća nastoji implementirati u svoju poslovnu strategiju kroz koncept DOP-a (Europski gospodarski i socijalni odbor, 2017).

U suvremenom poslovanju dobar strateški menadžment preduvjet je koji bi poduzeće trebalo ispuniti kako bi spremno odgovorilo izazovima na poslovnom planu i uspjelo u okruženju koje se mijenja. U interesu je poduzeća definirati strategiju koja će mu omogućiti ostvarivanje održive konkurentske prednosti u tržišnoj utakmici, što uključuje oblikovanje i ostvarivanje strategije društvene odgovornosti. Prema Thompsonu (2008) strategija društvene odgovornosti trebala bi sadržavati primjenu etičke strategije i poštivanje etičkih načela, priloge u dobrotvorne svrhe, novčane donacije i dobrovoljni angažman zaposlenika uključenih u aktivnosti zajednice, podržavanje raznih organizacijskih aktivnosti, akcije za poboljšanje života ljudi u nepovoljnom položaju, akcije za zaštitu i unaprjeđenje kvalitete okoliša, akcije za kreiranje radnog okruženja koje unaprjeđuje kvalitetu života zaposlenika i poduzeće stvara izvrsnim mjestom za rad te akcije za stvaranje radne snage koja je raznolika s obzirom na spol, rasu, podrijetlo i ostale specifične aspekte različitih zaposlenika.

Područja interesa kojima se DOP bavi sve su brojnija, a mogu se izdvojiti tri osnovna: okoliš, norme poslovnog upravljanja i ljudska prava. Tako su formulirane brojne vanjske norme, mjerila i smjernice za očuvanje okoliša, kao što je npr. standard Međunarodne organizacije za normizaciju ISO 14000, Povelja o održivom razvoju za poslovni sektor Međunarodne trgovinske komore, CERES-ova načela, UN-ov Globalni sporazum i Globalna inicijativa za izvještavanje (GRI), Program ekološkog upravljanja i nadzora (EMAS) Europske Unije, ali i kodeksi ponašanja u poduzećima koji štite ljudska prava zaposlenika i dr. (Bagić i sur., 2004).

Praksa primjene DOP-a u velikoj mjeri ovisi o samom poduzeću, njegovoj misiji, viziji i strategiji, korporativnoj kulturi te mnogim drugim čimbenicima koji utječu na način uključivanja i provedbu DOP-a u poslovnom upravljanju. U današnje vrijeme prisutan 
je uzlazni trend primjene koncepta DOP-a i to posebno u razvijenim zemljama, a tako i u Hrvatskoj, s obzirom na to da se svijest o potrebi odgovornog društva sve više razvija te unaprjeđuju procesi involviranja onih postupaka i akcija koje mogu osigurati dobrobit osnovnoj djelatnosti poduzeća i društvu u cjelini.

\subsection{Značajke i obilježja DOP-a u Republici Hrvatskoj}

DOP u Hrvatskoj počinje povećanim interesom za europsku tržǐ̌nu praksu nakon prihvaćanja kandidature za članstvo u EU te prvom konferencijom o DOP-u pod nazivom „Agenda 2005“ krajem 2004. (Hubak, 2010). Godine 2006. potpisan je Sporazum o suradnji između Hrvatske gospodarske komore (HGK) i Hrvatskog poslovnog savjeta za održivi razvoj (HR PSOR) s ciljem razvoja metodologije vrednovanja društveno odgovornih praksi njihovih članica te osmišljavanja nagrade kojom bi se vrednovale odgovorne poslovne prakse poduzeća i dodjeljivale ih na godišnjoj razini (HGK, 2010). Indeks DOP-a (HR PSOR, 2016b) je metodologija za ocjenjivanje najboljih poslovnih praksi hrvatskih poduzeća, a ujedno je i nagrada koju jednom godišnje u kategoriji malih, srednjih, velikih i javnih poduzeća zajednički dodjeljuju HGK i HR PSOR (HR PSOR, 2016a). U svrhu poticanja DOP-a, 2010. g. osnovana je Nacionalna mreža za DOP - nezavisno krovno tijelo koje je sastavljeno od organizacija javnog, privatnog i civilnog sektora $s$ ciljem okupljanja dionika i povećanja broja domaćih poduzeća koja strateški provode DOP, pokretanja dijaloga između poduzeća zainteresiranih za razvoj DOP-a, stvaranje dobrih praksi i dr. (Krpeljević, 2011).

Važnost i utjecaji primjene DOP-a od prve konferencije do danas pojačano se razvijaju te se organiziraju mnogi projekti i edukacije o njegovoj primjeni u poslovanju. Najrelevantnije informacije o vrstama i načinima provođenja DOP-a hrvatskih poduzeća dostupne su na internetskim stranicama HR PSOR-a na kojima su objavljena sva Izvješća o DOP-u hrvatskih poduzeća. Primjera dobre prakse DOP-a u hrvatskim je poduzećima sve više iako je DOP na niskom stupnju razvijenosti, kao što je i vrlo mali postotak poduzeća koji na svojim mrežnim stranicama objavljuju nefinancijske izvještaje (Kovač i Ćorić, 2016).

Prema provedenom istraživanju iz 2013. o primjeni društveno odgovornog poslovanja u Republici Hrvatskoj (Vrdoljak Raguž i Hazdovac, 2014), poduzeća u Hrvatskoj dokazuju dobro razvijenu i učestaliju praksu u području kvalitete, zaštite potrošača, okoliša, ulaganja u zajednicu itd., dok bi u područjima korporacijskog upravljanja, integriranja DOP-a u procese procjene rizika i razvoju poslovne strategije primjerice, trebala uložiti dodatne napore. DOP je prisutan u sve većem obujmu što potiče optimističan stav i prosperitetnu održivu budućnost.

\subsection{Proces donošenja odluke o kupnji}

Iz perspektive marketinga, cilj svakog marketinškog stručnjaka je kreiranje proizvoda ili usluga prema željama i potrebama kupaca i / ili potrošača u svrhu zadovoljenja njihovih potreba. U tom složenom i dinamičnom procesu potrebno je prepoznati čimbenike koji 
utječu na potrošače, njihovo ponašanje i odluke. Spoznaja potrošačeve potrebe prva je faza procesa donošenja odluke o kupnji koja proistječe iz svojevrsne nelagode ili želje koju potrošač osjeća, a može nastati kao posljedica određenih stimulansa. Kotler i suradnici (1999) navode unutrašnje i vanjske stimulanse koji pokreću potrošačevu svijest. Unutrašnji dovode do nelagode i uopćenog nezadovoljstva, a vanjski dolaze kao poticaji izvana - marketinški ili neki drugi koji potiču potrošača da zapazi problem (Previšić i Ozretić-Došen, 2007).

Sljedeća faza u procesu donošenja kupovne odluke odnosi se na traženje informacija (Kotler i sur., 2006). U toj fazi potrebno je razmotriti tri važna elementa u traženju informacija, a to su prema Kesić (2006) i Previšić i Ozretić-Došen (2007) izvori informacija, strategije traženja i opseg traženja. Izvori informacija mogu biti marketinški (oglašavanje, prodaja, internet, uređenje izloga i sl.) i nemarketinški (izvori koji ne ovise o poduzeću ili organizaciji - npr. specijalizirani časopisi, stručna izvješća, „WOM“ (Word of Mouth) marketing - odnosi se na širenje informacija među prijateljima i znancima, što ima veći stupanj vjerodostojnosti od marketinških izvora). Strategija traženja informacija odnosi se na način prikupljanja informacija, a može se promatrati kroz tri kupovne situacije ovisno o tome radi li se o prvoj kupnji, modificiranoj kupnji (kada se promijene pojedina obilježja, uvjeti na tržištu ili oboje) ili rutinskoj kupnji (Kesić, 2006; Previšić i Ozretić-Došen, 2007).

Obilježja faze u kojoj potrošač ocjenjuje različite mogućnosti i procesuira jednu po jednu marku na način da uspoređuje njihova svojstva sa željenim atributima, karakteristika je treće faze u procesu donošenja kupovne odluke, a to je faza vrednovanja alternativa. Prema Kesić (2006), dva su osnovna oblika vrednovanja alternativa: kompenzacijsko i nekompenzacijsko odlučivanje. Prilikom kompenzacijskog vrednovanja alternativa potrošač kompenzira manje vrijedna obilježja s više vrednovanima istog proizvoda. Pritom bi ona opcija koja ima najviše pozitivnih obilježja, na kraju trebala biti i kupljena. Pretposljednja faza kupovnog procesa odnosi se na kupnju što predstavlja pravni i / ili fizički prelazak proizvoda u vlasništvo kupca (Kesić, 2016; Previšić i Ozretić-Došen, 2007). Iz perspektive ponašanja potrošača, prilikom tzv. „rutinske“ kupnje, proces se nastavlja i nakon kupnje i konzumiranja proizvoda.

U poslijekupovnom ponašanju kao posljednjoj fazi, potrošač vrednuje dobivenu s očekivanom vrijednošću proizvoda. Ovo vrednovanje od strane potrošača odnosi se na proces aktivne psihološke uključenosti u kojoj razmatra i valorizira odabranu mogućnost u odnosu na sve ostale koje je mogao odabrati (Previšić i Ozretić-Došen, 2007). Ukoliko potrošač doživi pozitivno iskustvo (odnosno, zadovoljan je proizvodom u svim, njemu bitnim segmentima), za očekivati je da će se ponovno odlučiti za kupnju istoga proizvoda, savjetovati druge o kupnji tog proizvoda, te da će postati naklonjen i drugim proizvodima istog poduzeća (Kotler i sur., 1999).

Veoma je bitno provoditi kontinuirana istraživanja, pratiti trendove te na vrijeme biti informiran o svim relevantnim čimbenicima. Oni uključuju: praćenje i redovito rješavanje prigovora i žalbi potrošača, uspostavljanje i provođenje potpune kontrole kvalitete, osiguravanje primjene individualnoga pristupa prema potrošaču i sl. Sve to potrebno je 
učiniti kako bi povećanje zadovoljstva potrošača bilo iznad realnog očekivanja, što bi doprinijelo učvršćivanju lojalnosti potrošača određenoj marki proizvoda.

\subsection{Temeljna obilježja ponašanja potrošača}

Ponašanje potrošača oduvijek je zanimalo marketinške stručnjake, odnosno proizvođače i ponuđače proizvoda ili usluga. Američko marketinško udruženje (AMA) ponašanje potrošača definira kao dinamičku interakciju spoznaje i čimbenika okruženja koji rezultiraju promjenom ponašanja potrošača (AMA, 2016). Kotler i sur. (2006) ponašanje potrošača razmatra u kontekstu krajnjih potrošača, pojedinaca i domaćinstava koji kupuju proizvode ili usluge za osobnu potrošnju. Prema Knežević i Bilić (2015) ponašanje potrošača čini niz psiholoških i fizičkih aktivnosti pojedinca i / ili kućanstva u procesu odabira, kupnje i konzumiranja proizvoda i / ili usluga, što vodi zaključku da ponašanje potrošača uključuje prijekupovne, kupovne i poslijekupovne psihološke i fizičke aktivnosti s ciljem zadovoljenja potreba. U svakoj spomenutoj aktivnosti potrošač sudjeluje u određenim ulogama - kao kupac, korisnik i platitelj.

U procesu istraživanja ljudskog ponašanja važno je shvatiti zašto se netko ponaša na određeni način, odnosno kako potrošači donose odluku o kupnji određenog proizvoda ili usluge (važno je pri odabiru istražiti odlučujuće faktore). Stoga je potrebno razmotriti osobne i društvene čimbenike te psihološke procese koji utječu na ponašanje potrošača. Osobni (tzv. „unutarnji“) čimbenici utječu na pojedinca i odnose se na područje njegovog stila života, znanja $i$ iskustva te su osobito značajni za ponašanje potrošača. Prema tim čimbenicima potrošač oblikuje svoje ponašanje i na jedinstveni način donosi svoje kupovne odluke. Osobnost neke osobe rezultat je njegovih individualnih obilježja. Osobni čimbenici, prema Kesić (2006), odnose se na područje stila života, znanja i iskustva potrošača (npr. motivi, percepcija, stavovi, vrijednosti, vjerovanja). Društveni čimbenici odnose se na varijable koje utječu na ponašanje potrošača u odnosu na okruženje (npr. kultura i potkultura, društvene klase, referentne grupe, obitelj). Čimbenici poput starosti potrošača, zanimanja, obrazovanja, ekonomske situacije, načina života i osobnosti te predodžbe o samome sebi, imaju određeni utjecaj na odluke kupca u procesu kupnje. Marketinški stručnjaci pokušavaju prepoznati grupe zaposlenih koje imaju iznadprosječni interes za njihove proizvode i usluge (Kotler i sur., 2006).U segmentu psiholoških procesa (informacije, učenje, promjene stavova) mogući su najveći utjecaji marketinških aktivnosti na ponašanje potrošača (Kesić, 2006).

Kumar (2017) u istraživanju ponašanja potrošača proučavanjem relevantne objavljene literature, ističe da ponašanje potrošača nije isto u svakoj situaciji i da se vremenom mijenja. Autor ističe različite čimbenike koji utječu na ponašanje potrošača, navodeći da se zbog promjena u tim čimbenicima mijenja i potrošačevo ponašanje. $U$ čimbenike koji utječu na ponašanje potrošača ubraja demografske čimbenike (spol, dob, stručna sprema, nacionalnost, primanja, zanimanje, „veličina“ obitelji), geografske (razmatranje razlikovnih elemenata s obzirom na područje življenja potrošača - npr. razlike u preferenciji s obzirom na okuse, navike potrošača u smislu konzumacije i sl.) te psihološke 
čimbenike (u kontekstu zadovoljenja potreba potrošača s obzirom na segment potreba prema Maslowljevoj hijerarhiji potreba - od osnovnih, fizioloških potreba, prema osobnoj aktualizaciji pojedinca). Navedene čimbenike ističe kao izuzetno važne iz aspekta provođenja procesa istraživanja tržišta od strane marketinških stručnjaka s obzirom na to da je potrošač u središtu svih marketinških aktivnosti.

U rezultatima provedenog istraživanja demografskih karakteristika hrvatskih potrošača s ciljem ispitivanja utječu li i na koji način, demografske karakteristike ispitanika na proces donošenja odluke o kupnji, Štulec i sur. (2017) ističu utjecaj spola koji je statistički značajan u fazi kupovine, dok je utjecaj dobi statistički značajan u fazi prepoznavanja potrebe, traženja informacija i u fazi kupnje. Nadalje, utjecaj obrazovanja i radnog statusa statistički je značajan u fazi prepoznavanja potrebe, traženja informacija, fazi vrednovanja alternativa i poslijekupnom vrednovanju, dok utjecaj osobnog prihoda ispitanika na proces donošenja odluke o kupnji nije statistički potvrđen.

Nadovezujući se na činjenicu da je DOP danas sve popularniji i široko zastupljen, poduzeća koja odluče primijeniti DOP u svoje poslovanje u smislu strateškog planiranja te ulaganja u dugoročni prosperitet, mogu očekivati višestruke koristi, na primjer: rast reputacije, sklonost prema poduzeću i motiviranost dionika, prije svega zaposlenika i potrošača. To u konačnici može rezultirati povratom ulaganja (Matešić i sur., 2015). Poduzeća ulažu velike napore u smislu angažmana marketinških stručnjaka kako bi zadovoljili potrebe potrošača u što je moguće većoj mjeri. Također, poduzeća nastoje primijeniti poslovnu strategiju koja će rezultirati određenim komparativnim prednostima u odnosu na konkurenciju, osiguravajući više vrijednosti društvu. Rezultati provedenog istraživanja Vrdoljak Raguž i Hazdovac (2014), vezano na odluku potrošača za proizvode društveno odgovornih poduzeća prilikom njihove odluke o kupnji, ukazuju na svojevrsne kontradiktorne zaključke. Oni se ogledaju u činjenici da potrošači prepoznaju pojam i značenje društvene odgovornosti, iako primjena društveno odgovornog poslovanja poduzeća zapravo nije pokazala osobitu važnost prilikom odabira proizvoda potrošača u smislu indikatora lojalnosti prema tim poduzećima ili markama proizvoda. S obzirom na aktualnost teme, ovim istraživanjem se, iz aspekta demografskih čimbenika: dob, spol i stručna sprema, nastojalo utvrditi:

- razinu znanja te upoznatost potrošača prehrambenih kompanija u Republici Hrvatskoj s pojmom društveno odgovornog poslovanja te

- postoji li razlika u strukturi potrošača u kontekstu percepcije i stavova vezanih uz njihov odabir i odluke o kupnji prehrambenih proizvoda.

\section{METODOLOGIJA}

\subsection{Razvoj instrumenata}

U ovome dijelu rada izneseni su podaci provedenog istraživanja o utjecaju društveno odgovornog poslovanja na ponašanje potrošača pri kupnji prehrambenih proizvoda u Republici Hrvatskoj. Procesom istraživanja obuhvaćeno je $\mathrm{N}=105$ ispitanika Republike 
Hrvatske. Korišten je prigodni uzorak, a anketa je provedena u listopadu i studenom 2017.

Definirani su sljedeći ciljevi istraživanja:

- utvrditi povezanost spola, dobi i stručne spreme ispitanika s njihovom upoznatosti $s$ pojmom DOP-a,

- utvrditi povezanost spola, dobi i stručne spreme ispitanika s njihovim interesom za DOP prehrambenih poduzeća te generalnim stavom o ponuđačima prehrambenih proizvoda koji provode DOP

- utvrditi povezanost spola, dobi i stručne spreme ispitanika s njihovom percepcijom kvalitete kao ključnog faktora pri odabiru prehrambenih proizvoda.

U radu su postavljene dvije hipoteze:

H1: Anketirani potrošači različitog spola, različite dobi odnosno različite stručne spreme statistički se značajno ne razlikuju $s$ obzirom na upoznatost $s$ pojmom društveno odgovornog poslovanja.

H2: Anketirani potrošači različitog spola, različite dobi odnosno različite stručne spreme statistički se značajno ne razlikuju s obzirom na izbor kvalitete kao odlučujućeg faktora prilikom odabira prehrambenog proizvoda.

Ispitanici su pružili podatke u upitnicima koji se odnose na sljedeće tri skupine podataka:

- opći podaci o ispitanicima (spol, dob, stručna sprema i sl. demografska obilježja);

- 18 pitanja o DOP-u;

- 16 pitanja o ponašanju potrošača u procesu kupnje prehrambenih proizvoda.

Osim općih podataka o ispitaniku, sva druga pitanja iz upitnika nalazila su se na skali Likertovog tipa (Petz, 2007) i na njih je trebalo odgovoriti nižim ili višim stupnjem slaganja. Suglasnost $s$ većinom ovih pitanja u upitniku je izražena na pet razina: $1=$ uopće nije ispravno (čvrsto se ne slažem); 2 = nije ispravno (ne slažem se); $3=$ ni istinito ni netočno (niti se slažem niti ne slažem); 4 = točno (slažem se); $5=$ potpuno istinito (čvrsto se slažem).

\subsection{Postupak prikupljanja podataka}

Pitanja u upitnicima bila su zatvorenog tipa, isključivo $s$ jednim mogućim odgovorom od više ponuđenih. Svi upitnici popunjavali su se online putem Google aplikacije. Iz dobivene Excel datoteke konvertirani su u SPSS datoteku. Na osnovi SPSS datoteke izvedene su sve vrste statističkih analiza programom SPSS Statistics for Windows, v. 17.0.

\subsection{Statističke tehnike}

U ovom istraživanju korištene su sljedeće metode statističke analize:

- deskriptivne metode (tablični prikazi, postoci, srednje vrijednosti, mjere disperzije);

- inferencijalne metode (Kolmogorov-Smirnovljev test normalnosti distribucije, hi-kvadrat test, Mann-Whitneyev U test, Kruskal-Wallisov $\mathrm{H}$ test, test razlike proporcija).

Zaključci u pogledu razlika i povezanosti među varijablama donošeni su na nivou signifikantnosti od 0,07 odnosno uz pouzdanost od 93\%. 


\section{ANALIZA PODATAKA}

Od desetak demografskih obilježja ispitanika u ovom su radu izdvojena tri najvažnija: spol, dob i stručna sprema. Prema spolu u anketi je sudjelovalo 27 muškaraca odnosno $26 \%$ i 75 žena odnosno $74 \%$. Struktura ispitanika prema spolu, dobi i stručnoj spremi navedena je u Tablici 1.

Tablica 1. Struktura anketiranih ispitanika prema spolu, dobi i stručnoj spremi

\begin{tabular}{|c|c|c|c|}
\hline \multicolumn{2}{|c|}{ Kategorije ispitanika } & $\mathrm{N}$ ispitanika & $\%$ ispitanika \\
\hline \multirow{2}{*}{ Spol: } & Muški & 27 & 26 \\
\hline & Ženski & 78 & 74 \\
\hline \multicolumn{2}{|c|}{ Ukupno po spolu } & 105 & 100 \\
\hline \multirow{6}{*}{ Dob: } & Do $25 \mathrm{~g}$ & 3 & 3 \\
\hline & $26-35$ & 24 & 23 \\
\hline & $36-45$ & 27 & 25 \\
\hline & $46-55$ & 36 & 34 \\
\hline & $56-65$ & 10 & 10 \\
\hline & $66+$ & 5 & 5 \\
\hline \multicolumn{2}{|c|}{ Ukupno po dobi } & 105 & 100 \\
\hline \multirow{5}{*}{ Stručna sprema: } & OŠ & 3 & 3 \\
\hline & SŠ (4 godine) & 24 & 23 \\
\hline & Dodiplomski studij & 20 & 19 \\
\hline & Diplomski studij & 48 & 45 \\
\hline & $\begin{array}{l}\text { Poslijediplomski i } \\
\text { doktorski studij }\end{array}$ & 10 & 10 \\
\hline \multicolumn{2}{|c|}{ Ukupno po stručnoj spremi } & 105 & 100 \\
\hline
\end{tabular}

U ovoj anketi dominiraju ispitanici ženskog spola (74\%), srednje dobi (između 46 i 55 godina, $34 \%$ ) te sa završenim diplomskim studijem (45\%). U nastavku su prezentirane apsolutne i relativne frekvencije dobivene na neka pitanja o DOP-u. Prvo od tih pitanja bilo je o tome jesu li upoznati s pojmom DOP. Pozitivnih odgovora je bilo 75 (71\%), a negativnih 30 (29\%).

Drugo pitanje bilo je zanima li se ispitanik za DOP prehrambenih poduzeća. Pozitivnih odgovora zabilježeno je 78 (74\%), negativnih samo četiri (4\%), dok se 23 ispitanika $(22 \%)$ odlučilo za neutralan odgovor „ne znam, ne mogu procijeniti“.

Treće pitanje glasilo je što za ispitanika znači pojam DOP. Odgovori su raznoliki, a iskazani su u Tablici 2. 
Tablica 2. Anketirani ispitanici prema odgovorima na pitanje što za njih znači pojam "druśtveno odgovorno poslovanje"

\begin{tabular}{|c|c|c|c|}
\hline Rbr. & Pojam „društveno odgovorno poslovanje“ znači... & $\mathrm{N}$ ispitanika & $\%$ ispitanika \\
\hline 1. & $\begin{array}{l}\text { Kada poduzeće integrira brigu za okoliš i društvo u } \\
\text { sustav donošenja odluka. }\end{array}$ & 36 & 34 \\
\hline 2. & $\begin{array}{l}\text { Poslovni model i način upravljanja u poduzeću u cilju } \\
\text { ostvarivanja dodatnog profita. }\end{array}$ & 3 & 3 \\
\hline 3. & $\begin{array}{l}\text { Kada poduzeće investira u ljudski kapital, okoliš i } \\
\text { odnose s dioničarima i ostalim interesno utjecajnim } \\
\text { skupinama. }\end{array}$ & 15 & 14 \\
\hline 4. & $\begin{array}{l}\text { Koncept koji poduzeća dobrovoljno prihvaćaju i } \\
\text { ugrađuju u svoje poslovanje s ciljem brige za društvena } \\
\text { pitanja. }\end{array}$ & 16 & 15 \\
\hline 5. & $\begin{array}{l}\text { DOP je doprinos koji poduzeće svojim temeljnim } \\
\text { aktivnostima ostvaruje u društvu. }\end{array}$ & 5 & 5 \\
\hline 6. & $\begin{array}{l}\text { Koncept putem kojeg poduzeća integriraju društvene i } \\
\text { ekološke ciljeve u svoje poslovne aktivnosti te odnose s } \\
\text { dionicima na dobrovoljnoj osnovi. }\end{array}$ & 26 & 25 \\
\hline 7. & $\begin{array}{l}\text { Poslovni koncept kojim poduzeće nastoji ostvariti } \\
\text { definirane promotivne ciljeve. }\end{array}$ & 4 & 4 \\
\hline & Ukupno & 105 & 100 \\
\hline
\end{tabular}

Svi odgovori u Tablici 2 čine sastavnicu pojma DOP-a. Trećina ispitanika odabrala je najčešće shvaćen koncept DOP-a (odgovor pod rednim brojem 1).

Iduće anketno pitanje bilo je koji je faktor za ispitanika odlučujući u procesu odabira i kupnje prehrambenih proizvoda. Odgovori su navedeni u Tablici 3.

Tablica 3. Anketirani ispitanici prema odgovorima na pitanje koji im je faktor odlučujući u procesu odabira i kupnje prehrambenih proizvoda

\begin{tabular}{|l|c|c|}
\hline \multicolumn{1}{|c|}{ Odlučujući faktor kod odabira } & N ispitanika & \% ispitanika \\
\hline Marka proizvoda & 6 & 6 \\
\hline Cijena & 11 & 10 \\
\hline Kvaliteta & 72 & 69 \\
\hline Promotivne aktivnosti & 4 & 4 \\
\hline Preporuke & 9 & 9 \\
\hline Informacije o provedbi DOP-a proizvođača & 3 & 3 \\
\hline Ukupno & 105 & 100 \\
\hline
\end{tabular}

Prevladavajući čimbenik u odabiru i kupnji prehrambenih proizvoda kod anketiranih ispitanika je kvaliteta (kod 69\% ispitanika) dok se za informacije o provedbi DOP-a proizvođača opredijelilo svega 3\% ispitanika. 
U Tablici 4 izneseni su stupnjevi slaganja anketiranih osoba s tvrdnjom da se prije kupnje prehrambenih proizvoda informiraju o ponuđačima koji provode DOP.

Tablica 4. Anketirani ispitanici prema stupnju slaganja s tvrdnjom o tome da se prije kupnje prehrambenih proizvoda informiraju o ponudačima koji provode DOP

\begin{tabular}{|l|c|c|}
\hline Stupanj slaganja s tvrdnjom & N ispitanika & \% ispitanika \\
\hline Izrazito se ne slažem & 4 & 4 \\
\hline Ne slažem se & 34 & 32 \\
\hline Niti se slažem, niti se ne slažem & 45 & 43 \\
\hline Slažem se & 22 & 21 \\
\hline Ukupno & 105 & 100 \\
\hline
\end{tabular}

Ako bi se odgovori, koji su navedeni u Tablici 4, kodirali na vrijednostima između 1 (izrazito se ne slažem) i 4 (slažem se), mogli bi se izračunati sljedeći deskriptivni pokazatelji: medijan od 3, aritmetička sredina od 2,81 standardna devijacija od 0,810 i koeficijent varijacije od $29 \%$. Prema tome, odgovori ispitanika su u prosjeku najbliži stavu „niti se slažem, niti se ne slažem“. Za potrebe inferencijalne statističke analize najmanja frekvencija od 4 (,izrazito se ne slažem“) pripojena je pojmu „ne slažem se“. Time su dobivene tri frekvencije od 38, 45 i 22 (u relativnom izrazu je to $36 \%, 43 \%$ i $21 \%$ ) za koje se može pretpostaviti da su slične normalnoj distribuciji.

Postoji li zaista ta sličnost, provjereno je na dva načina:

- pomoću Kolmogorov-Smirnovljevog testa čiji su rezultati pokazali $(\mathrm{z}=2,404$ $\mathrm{p}<0,001)$ da se distribucija statistički značajno razlikuje od normalne;

- pomoću hi-kvadrat testa kod kojeg su pretpostavljene vrijednosti distribuirane u omjeru $25 \%, 50 \%$ i $25 \%$ odnosno $26,25+52,5+26,25=105$. Rezultati i ovog testa $\left(\chi^{2}=7,019, \mathrm{df}=2, \mathrm{~N}=105, \mathrm{p}=0,030\right)$ pokazuju da se navedena distribucija statistički značajno razlikuje od normalne distribucije.

Stoga je kod inferencijalne statističke analize ove varijable neophodno koristiti neparametrijske metode analize.

$\mathrm{Za}$ potrebe ovih testova ispitanici su (zbog manjeg uzorka) razvrstani u samo tri skupine prema dobi: mlađi (27 ispitanika s 18-35 godina), srednji (63 ispitanika s 36-55 godina) i stariji (15 ispitanika s 56 godina i više). Također je provedeno objedinjavanje kategorija stručne spreme tako da su formirane samo tri skupine: OŠ i SŠ (27 ispitanika), dodiplomski i diplomski studij (68 ispitanika) i poslijediplomski i doktorski studij (10 ispitanika).

Prvu skupinu testova čine hi-kvadrat testovi kojima se provjerava postoji li statistički značajna povezanost između spola, dobi i stručne spreme ispitanika kao nezavisnih varijabli i upoznatosti ispitanika s pojmom DOP-a. Rezultati provedenih testova pregledno su prezentirani u Tablici 5 . 


\section{Tablica 5. Rezultati hi-kvadrat testova}

\begin{tabular}{|c|c|c|c|c|c|c|}
\hline Rbr. & Varijable u kontingencijskoj tablici & 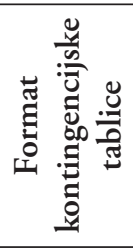 & $\mathrm{N}$ & $\chi^{2}$ & df & $\mathrm{p}$ \\
\hline 1. & Upoznatost s pojmom DOP-a prema spolu & $2 \times 2$ & 105 & $1,198^{* *}$ & 1 & 0,274 \\
\hline 2. & $\begin{array}{l}\text { Upoznatost s pojmom DOP-a prema dobi } \\
\text { (mlađa, srednja i starija dob) }\end{array}$ & $3 \times 2$ & 105 & 1,130 & 2 & 0,568 \\
\hline 3. & $\begin{array}{l}\text { Upoznatost s pojmom DOP-a prema stručnoj } \\
\text { spremi (OŠ i SS̆, dodipl. i dipl. studij, } \\
\text { postdipl. i doktorski studij) }\end{array}$ & $3 \times 2$ & 105 & 5,448 & 2 & $0,066^{*}$ \\
\hline
\end{tabular}

* statistička značajnost do 7\%

** hi-kvadrat vrijednost dobivena uz Yatesovu korekciju

Zaključci na osnovi provedenih testova su sljedeći:

- Ne postoji statistički značajna povezanost između spola i upoznatosti ispitanika $s$ pojmom DOP-a $(\mathrm{p}=0,274)$. Istina, $81 \%$ muškaraca su upoznati s tim pojmom, te $68 \%$ žena, ali je ta razlika još uvijek premala da bi bila statistički značajna;

- Ne postoji statistički značajna povezanost između dobi i upoznatosti ispitanika s pojmom DOP-a $(\mathrm{p}=0,568)$;

- Postoji statistički značajna povezanost između stručne spreme i upoznatosti ispitanika s pojmom DOP-a $(\mathrm{p}=0,066)$. Prema tablici kontingencije (Tablica 6) s pojmom DOP-a upoznato je $56 \%$ ispitanika s OŠ i SŠ, $75 \%$ ispitanika s dodiplomskim i diplomskim studijem te $90 \%$ ispitanika s postdiplomskim i doktorskim studijem. Prema tome, s porastom stupnja obrazovanja raste i postotak ispitanika koji poznaju pojam DOP.

Tablica 6. Odnos izmedu stručne spreme ispitanika i upoznatosti ispitanika s pojmom DOP

\begin{tabular}{|l|c|c|c|}
\hline \multirow{2}{*}{\multicolumn{1}{|c|}{ Stručna sprema }} & \multicolumn{2}{|c|}{$\begin{array}{c}\text { Upoznatost s } \\
\text { pojmom DOP-a }\end{array}$} & \multirow{2}{*}{ Ukupno } \\
\cline { 2 - 3 } & $\mathrm{Da}$ & $\mathrm{Ne}$ & \\
\hline Osnovna škola ili srednja škola & 15 & 12 & 27 \\
\hline Dodiplomski ili diplomski studij & 51 & 17 & 68 \\
\hline Postdiplomski ili doktorski studij & 9 & 1 & 10 \\
\hline \multicolumn{1}{|c|}{ Ukupno } & 75 & 30 & 105 \\
\hline
\end{tabular}

Drugu skupinu testova čine testovi razlike proporcija. Svrha im je provjeriti postoji li statistički značajna razlika u zanimanju ispitanika za DOP prehrambenih poduzeća između ispitanika različitog spola, različite dobi i različite stručne spreme. Rezultati provedenih testova pregledno su prezentirani u Tablici 7. 
Tablica 7. Rezultati testova razlike proporcija

\begin{tabular}{|c|c|c|c|c|c|c|}
\hline Rbr. & Varijabla & $\begin{array}{c}\text { Grupa } \\
\text { ispitanika }\end{array}$ & $\mathrm{N}$ & $\begin{array}{c}\text { Proporcija } \\
\text { zainteresiranih } \\
\text { za DOP } \\
\end{array}$ & $t / \chi^{2}$ & $\mathrm{p}$ \\
\hline 1. & $\begin{array}{l}\text { Zanimanje za DOP } \\
\text { prehrambenih } \\
\text { poduzeća prema spolu }\end{array}$ & $\begin{array}{l}\text { Muški } \\
\text { Ženski }\end{array}$ & $\begin{array}{l}27 \\
78\end{array}$ & $\begin{array}{l}24 / 27=0,889 \\
54 / 78=0,692\end{array}$ & $\mathrm{t}=2,014$ & $0,047^{*}$ \\
\hline 2. & $\begin{array}{l}\text { Zanimanje za DOP } \\
\text { prehrambenih } \\
\text { poduzeća prema dobi }\end{array}$ & $\begin{array}{l}\text { Mladi } \\
\text { Srednji } \\
\text { Stariji }\end{array}$ & $\begin{array}{l}27 \\
63 \\
15\end{array}$ & $\begin{array}{l}17 / 27=0,630 \\
48 / 63=0,762 \\
13 / 15=0,867\end{array}$ & $\chi^{2}=0,806$ & 0,668 \\
\hline 3. & $\begin{array}{l}\text { Zanimanje za DOP } \\
\text { prehrambenih } \\
\text { poduzeća prema } \\
\text { stručnoj spremi }\end{array}$ & $\begin{array}{c}\text { OŠ i SŠ } \\
\text { Dodipl. i dipl. } \\
\text { Postdipl. i dokt. }\end{array}$ & $\begin{array}{l}27 \\
68 \\
10\end{array}$ & $\begin{array}{c}20 / 27=0,741 \\
49 / 68=0,721 \\
9 / 10=0,900\end{array}$ & $\chi^{2}=0,378$ & 0,828 \\
\hline
\end{tabular}

* statistička značajnost do $7 \%$

Zaključci na osnovi provedenih testova su sljedeći:

- Postoji statistički značajna razlika između spola i zanimanja ispitanika za DOP prehrambenih poduzeća $(\mathrm{p}=0,047)$. Naime, muškarci iskazuju značajno veći interes $(88,9 \%)$ od žena $(69,2 \%)$;

- Ne postoji statistički značajna razlika između dobi i zanimanja ispitanika za primjenu DOP-a u prehrambenim poduzećima $(\mathrm{p}=0,668)$. To je zanimanje manje kod mlađih, a veće kod starijih ispitanika, ali ta razlika još nije dovoljno velika da bi bila statistički značajna;

- Ne postoji statistički značajna razlika između stručnih sprema i zanimanja ispitanika za primjenu DOP-a u prehrambenim poduzećima ( $\mathrm{p}=0,828)$. Najveće zanimanje pokazuju ispitanici s postdiplomskim ili doktorskim studijem (90,0\%).

Tablica 8. Rezultati testova razlike proporcija

\begin{tabular}{|c|c|c|c|c|c|c|}
\hline Rbr. & Varijabla & $\begin{array}{c}\text { Grupa } \\
\text { ispitanika }\end{array}$ & $\mathrm{N}$ & \begin{tabular}{|c|} 
Proporcija \\
zainteresiranih \\
za DOP \\
\end{tabular} & $\mathrm{t} / \chi^{2}$ & $\mathrm{p}$ \\
\hline 1. & $\begin{array}{l}\text { Kvaliteta kao odlučujući faktor } \\
\text { odabira prehrambenih proizvoda } \\
\text { prema spolu }\end{array}$ & $\begin{array}{l}\text { Muški } \\
\text { Ženski }\end{array}$ & $\begin{array}{l}27 \\
78\end{array}$ & $\begin{array}{l}20 / 27=0,741 \\
52 / 78=0,667\end{array}$ & $t=0,715$ & 0,476 \\
\hline 2. & $\begin{array}{l}\text { Kvaliteta kao odlučujući faktor } \\
\text { odabira prehrambenih proizvoda } \\
\text { prema dobi }\end{array}$ & $\begin{array}{l}\text { Mladi } \\
\text { Srednji } \\
\text { Stariji }\end{array}$ & \begin{tabular}{|l|}
27 \\
63 \\
15 \\
\end{tabular} & $\begin{array}{l}15 / 27=0,556 \\
47 / 63=0,746 \\
10 / 15=0,667\end{array}$ & $\chi^{2}=1,009$ & 0,604 \\
\hline 3. & $\begin{array}{l}\text { Kvaliteta kao odlučujući faktor } \\
\text { odabira prehrambenih proizvoda } \\
\text { prema stručnoj spremi }\end{array}$ & $\begin{array}{l}\text { OŠ i ŠS } \\
\text { Dodipl. i dipl. } \\
\text { Postdipl. i dokt. }\end{array}$ & $\begin{array}{l}27 \\
68 \\
10 \\
\end{array}$ & $\begin{array}{c}19 / 27=0,704 \\
47 / 68=0,691 \\
6 / 10=0,600\end{array}$ & $\chi^{2}=0,123$ & 0,940 \\
\hline
\end{tabular}


U izlaganju rezultata deskriptivne analize navedeno je da je kod pitanja „Koji su odlučujući faktori u procesu odabira i kupnje prehrambenih proizvoda?" najčešći odgovor bio kvaliteta (za 69\% ispitanika). Stoga je svrha ovih testova provjeriti postoji li statistički značajna razlika u navođenju kvalitete kao odlučujućeg faktora kupnje kod ispitanika različitog spola, različite dobi i različite stručne spreme. Rezultati provedenih testova pregledno su prezentirani u Tablici 8.

Zaključci na osnovi provedenih testova su sljedeći:

- Ne postoji statistički značajna razlika između muškaraca i žena s obzirom na kvalitetu kao odlučujući faktor odabira prehrambenog proizvoda ( $\mathrm{p}=0,476)$;

- Ne postoji statistički značajna razlika između ispitanika različite dobi s obzirom na kvalitetu kao odlučujući faktor odabira prehrambenog proizvoda $(\mathrm{p}=0,604)$;

- Ne postoji statistički značajna razlika između različitih stručnih sprema ispitanika s obzirom na kvalitetu kao odlučujući faktor odabira prehrambenog proizvoda $(\mathrm{p}=0,940)$.

Treću skupinu testova čine U i H testovi. Varijabla B3 izražava stav potrošača u pogledu informiranosti o ponuđačima koji provode DOP. Kako ta varijabla nije normalno distribuirana to je za testiranje razlika u stavovima potrošača različitog spola, različite dobi odnosno različite stručne spreme potrebno koristiti neparametrijske testove. To su Mann-Whitneyev U test u slučaju kada kategorijalna varijabla ima samo dva modaliteta kao što je spol, odnosno Kruskal-Wallisov $\mathrm{H}$ test kada kategorijalna varijabla ima tri ili više modaliteta kao što su dob ili stručna sprema. Svrha je ovih testova provjeriti postoji li statistički značajna razlika u vrijednosti medijana za ispitanike različitog spola, različite dobi i različite stručne spreme. Rezultati provedenih $\mathrm{U}$ odnosno $\mathrm{H}$ testova pregledno su prezentirani u Tablici 9.

Tablica 9. Rezultati U odnosno $H$ testova razlike medijana

\begin{tabular}{|c|c|c|c|c|c|c|}
\hline Rbr. & Varijabla & $\begin{array}{c}\text { Grupa } \\
\text { ispitanika }\end{array}$ & $\mathrm{N}$ & $\begin{array}{l}\text { Sredine } \\
\text { rangova }\end{array}$ & $\mathrm{U} / \chi^{2}$ & $\mathrm{p}$ \\
\hline 1. & $\begin{array}{l}\text { Stav potrošača o ponuđačima } \\
\text { prehrambenih proizvoda koji } \\
\text { provode DOP prema spolu }\end{array}$ & $\begin{array}{l}\text { Muški } \\
\text { Ženski }\end{array}$ & $\begin{array}{l}27 \\
78\end{array}$ & $\begin{array}{l}59,22 \\
50,85\end{array}$ & $U=885$ & 0,185 \\
\hline 2. & $\begin{array}{l}\text { Stav potrošača o ponuđačima } \\
\text { prehrambenih proizvoda koji } \\
\text { provode DOP prema dobi }\end{array}$ & $\begin{array}{l}\text { Mladi } \\
\text { Srednji } \\
\text { Stariji }\end{array}$ & $\begin{array}{l}27 \\
63 \\
15\end{array}$ & $\begin{array}{l}44,44 \\
55,14 \\
53,40 \\
\end{array}$ & $\chi^{2}=3,591$ & 0,166 \\
\hline 3. & $\begin{array}{l}\text { Stav potrošača o ponuđačima } \\
\text { prehrambenih proizvoda } \\
\text { koji provode DOP prema } \\
\text { stručnoj spremi }\end{array}$ & $\begin{array}{l}\text { OŠ i Š } \\
\text { Dodipl. i dipl. } \\
\text { Postdipl. i dokt. }\end{array}$ & $\begin{array}{l}27 \\
68 \\
10\end{array}$ & $\begin{array}{l}62,65 \\
49,94 \\
47,75\end{array}$ & $\chi^{2}=4,270$ & 0,118 \\
\hline
\end{tabular}

Zaključci na temelju provedenih testova su sljedeći:

- Ne postoji statistički značajna razlika između muškaraca i žena s obzirom na njihov stav o ponuđačima prehrambenih proizvoda koji provode DOP $(\mathrm{p}=0,185)$; 
- Ne postoji statistički značajna razlika između mlađih, srednjih i starijih ispitanika s obzirom na njihov stav o ponuđačima prehrambenih proizvoda koji provode DOP $(\mathrm{p}=0,166)$;

- Ne postoji statistički značajna razlika između različitih stručnih sprema ispitanika s obzirom na njihov stav o ponuđačima prehrambenih proizvoda koji provode DOP $(\mathrm{p}=0,118)$.

Četvrtu skupinu testova predstavlja hi-kvadrat test:

- U anketi je 75 ispitanika (71\%) odgovorilo da je upoznato s pojmom DOP-a;

- U anketi je 78 ispitanika (74\%) odgovorilo da ih zanima DOP prehrambenih poduzeća;

- Svaki odgovor u Tablici 2 o značenju pojma DOP-a je ispravan i predstavlja pojedini vid DOP-a, sastavni dio pojma DOP-a. Znači, neka poduzeća su primjerice, isključivo orijentirana na očuvanje prirodnih resursa i zaštitu okoliša, neka u svom poslovanju uključuju aktivnosti na tom polju, ali i u nekom drugom, npr. najviše su angažirana u smislu provedbe poslovne djelatnosti poštujući ljudska prava i sl. Dakle, poduzeća u svoje poslovanje uključuju one aktivnosti DOP-a koje su u skladu s njihovim strateškim ciljevima i poslovnim mogućnostima. U skladu s time, rezultati provedenog istraživanja pokazuju da su svi anketirani potrošači korektno odgovorili na pitanje što za njih znači pojam DOP-a.

\section{ZAKLJUČAK}

Društvena odgovornost poslovanja jedna je od uobičajenih poslovnih praksi našeg vremena. Uspostavljanje strategije DOP-a ključna je komponenta konkurentnosti poduzeća i poslovni koncept koji bi svako poduzeće trebalo usvojiti i provoditi u smislu uspostavljanja politike i postupaka koji integriraju socijalna, ekološka, etička i ljudska prava ili pitanja potrošača u poslovne procese i poslovnu strategiju, i to u uskoj suradnji s dionicima. Cilj poduzeća orijentiranog prema DOP-u postizanje je pozitivnog utjecaja na društvo u cjelini, uz istodobno stvaranje zajedničkih vrijednosti za vlasnike poduzeća, njegove zaposlenike, dioničare i ostale dionike.

U ovom istraživanju nastojala se utvrditi razina znanja kao i upoznatost potrošača prehrambenih poduzeća u RH s pojmom društveno odgovornog poslovanja. Također se pokušalo utvrditi postoji li razlika u strukturi potrošača u kontekstu percepcije i stavova u vezi s njihovim odabirom i odlukom o kupnji prehrambenih proizvoda. Rezultati su pokazali da ne postoji statistički značajna povezanost između spola i dobi $s$ jedne strane te upoznatosti ispitanika s pojmom DOP-a s druge strane. Međutim, utvrđeno je da postoji statistički značajna povezanost između stručne spreme i upoznatosti ispitanika s pojmom DOP-a. Potrošači niže stručne spreme manje su upoznati s pojmom DOP-a, dok su oni $s$ višom bolje upoznati s pojmom DOP-a.

Nadalje, utvrđena je statistički značajna razlika između spola i zanimanja ispitanika za DOP prehrambenih poduzeća, pri čemu muškarci iskazuju statistički značajno veći in- 
teres od žena. Rezultati su pokazali da ne postoji statistički značajna razlika između dobi i zanimanja ispitanika za DOP, kao ni između stručne spreme i zanimanja ispitanika za DOP prehrambenih poduzeća.

Kako se u prvoj hipotezi tvrdilo da nema razlike u upoznatosti ispitanika s pojmom DOP-a s obzirom na sve tri karakteristike (spol, dob i stručnu spremu) ona se može samo djelomično prihvatiti (razlike su statistički značajne s obzirom na stručnu spremu, ali nisu s obzirom na spol i dob).

Anketirani potrošači različitog spola, dobi i stručne spreme statistički se značajno ne razlikuju s obzirom na izbor kvalitete kao odlučujućeg faktora u odabiru prehrambenog proizvoda, što je bila druga istraživačka hipoteza. S obzirom na navedeno, ova hipoteza je prihvaćena.

Konačno, istraživanje je pokazalo da su ispitanici uglavnom upoznati s pojmom DOP-a. Na pitanje o tome što podrazumijevaju pod pojmom DOP-a ispitanici pretežno odgovaraju:

- da je to stanje kada poduzeće u svoje poslovanje i donošenje odluka integrira brigu za okoliš i društvo;

- da je to koncept putem kojeg poduzeća integriraju društvene i ekološke ciljeve u svoje poslovne aktivnosti.

Od sedam ponuđenih odgovora koji su svi sastavnice pojma DOP-a, ova dva odgovora odabralo je $59 \%$ anketiranih potrošača.

Bavljenje temama povezanima s društveno odgovornim poslovanjem postaje sve popularnija praksa u svim razvijenim društvima. DOP je proces upravljanja i uravnoteženja odnosa između poduzeća i njegovih mnogobrojnih dionika na profesionalan, proaktivan, odgovoran i održiv način. Načela razvoja učinkovite strategije DOP-a podrazumijevaju uključivanje svega što poduzeće radi pa je stoga potrebno primijeniti neke od strategija komunikacije u smislu priopćenja za javnost, kako bi informacije o aktivnostima u segmentu DOP-a poduzeća, bile što dostupnije krajnjem potrošaču. Program DOP-a poduzećima može donijeti mnoge koristi u pogledu konkurentskih prednosti, upravljanja rizikom, izbjegavanja troškova, utjecaja na lojalnost potrošača itd.

Ograničenje ove vrste istraživanja predstavljaju izjave ispitanika, a ne njihovo stvarno ponašanje. Kako bi se smanjila ta razlika, u budućnosti bi trebalo pribjegavati primjeni eksperimenta.

\section{LITERATURA}

American Marketing Association - AMA (2016). Consumer Behavior SIG. URL: https:// www.ama.org/ama_cohort/cbsig/ (09.12.2016.)

Bačun, D., Matešić, M. i Omazić, M. A. (2012). Leksikon održivog razvoja. Zagreb: Hrvatski poslovni savjet za održivi razvoj.

Bagić, A., Škrabalo, M. i Narančić L. (2004). Pregled društvene odgovornosti poduzeća. Zagreb: AED-Academy for Educational Development. 
Bagić, A., Škrabalo, M. i Narančić, L. (2006). Društvena odgovornost poduzeća u Hrvatskoj. Zagreb: AED-Academy for Educational Development.

Buble, M. (2009). Menadžment. Split: Ekonomski fakultet Sveučilišta u Splitu.

Carroll, A. B. i Shabana, K. M. (2010). The Business Case for Corporate Social Responsibility: A Review of Concepts, Research and Practice. International Journal of Management Reviews, 12(1): 85-105.

Crowther, D. i Güler, A. (2008). Corporate Social Responsibility. Frederiksberg: Ventus Publishing Aps.

Ćorić, G. (2008). Što je društvena odgovornost? Pomak online - Magazin za društveni razvitak, 15. travnja 2008. URL: http://www.pomakonline.com/content/view/100/60 (15.11.2016.)

Europski gospodarski i socijalni odbor (2017). Mišljenje Europskog gospodarskog i socijalnog odbora o „Odgovarajućem okviru za transparentnost trgovačkih društava“ (samoinicijativno mišljenje). Službeni list Europske unije, 75(60): 14-20.

Hrvatska gospodarska komora - HGK (2010). Razvoj projekta Indeks DOP-a. URL: https://dop.hgk.hr/povijest-projekta/ (08.12.2016.)

Hrvatski poslovni savjet za održivi razvoj - HR PSOR (2016a). Indeks DOP-a. Društveno odgovorno poslovanje u Hrvatskoj. URL: https://www.hrpsor.hr/indeks-dop-a (08.12.2016.)

Hrvatski poslovni savjet za održivi razvoj - HR PSOR (2016b). Nefinancijski izvještaji hrvatskih poduzeća. URL: https://www.hrpsor.hr/nefinancijski-izvjestaji-hrvatskih- poduzeca (08.12.2016.)

Hubak, D. (2010). Marketinška dimenzija društveno odgovornog poslovanja. Ekonomski fakultet sveučilišta u Zagrebu - serija članaka u nastajanju, br. 10-10. URL: http://web.efzg.hr/RePEc/pdf/Clanak\%2010-10.pdf (08.12.2016.).

Kesić, T. (2006). Ponašanje potrošača. Zagreb: Opinio d.o.o.

Knežević, S. i Bilić, N. (2015). Utjecaj kulture na ponašanje potrošača prehrambenih proizvoda u Republici Hrvatskoj. Praktični menadžment: stručni časopis za teoriju i praksu menadžmenta, 6(1): 157-164.

Kotler, P., Armstrong, G., Saunders, J. i Wong, V. (1999). Principles of Marketing. Harlow, UK: Prentice Hall Europe.

Kotler, P., Wong, V., Saunders, J. i Armstrong G. (2006). Osnove marketinga. Zagreb: Mate - marketing tehnologija.

Kotler, P. i Lee, N. (2009). Drustveno odgovorno poslovanje - suvremena teorija i najbolja praksa. Zagreb: M.E.P.

Kovač, D. i Ćorić, G. (2016). Primjena društveno odgovornog poslovanja u trgovačkim društvima u portfelju Republike Hrvatske. U: Matešić, M. (ur.), Zbornik radova 8. konferencije o društveno odgovornom poslovanju - DOP (str. 181-195). Zagreb: Hrvatski poslovni savjet za održivi razvoj - HR PSOR.

Krkač, K. (2007). Poslovna etika i korporacijska društvena odgovornost. Zagreb: Mate marketing tehnologija. 
Krpeljević, K. (2011). Radionica. Od korporativne filantropije do strateških ulaganja u društveni razvoj. Pomak online - Magazin za društveni razvitak, 27. lipnja 2011. URL: http://www.pomakonline.com/content/view/621/35 (08.12.2016.)

Kumar, R. (2017). Consumer Behaviour and Role of Consumer. Research in Marketing. Journal of Commerceand Trade, 12(1): 65-76.

Letica, B. (2010). Doba odgovornosti: Korporacijska drusttvena odgovornost u vrijeme svjetske financijske krize. Zagreb: Mate - marketing tehnologija.

Matešić, M., Pavlović, D. i Bartoluci, D. (2015). Drustveno odgovorno poslovanje. Zagreb: Visoka poslovna škola Libertas.

Pavić-Rogošić, L. (2010). Održivi razvoj. Odraz. URL: http://www.odraz.hr/media/21831/odrzivi_razvoj.pdf (15.11.2016.)

Petz, B. (2007). Osnovne statističke metode za nematematičare. Slap. Zagreb.

Previšić, J. i Ozretić-Došen, Đ. (2007). Osnove marketinga. Zagreb: Adverta

Štulec, I., Petljak, K. i Rakarić, J. (2017). Utjecaj demografskih karakteristika potrošača na proces donošenja odluke o kupovini. Ekonomska misao i praksa, 26(1): 381-404.

Tench, R. i Yeomans, L. (2009). Exploring public relations. Harlow, England; New York, NY: FT Prentice Hall.

Thompson, A. M. (2008). Strategic Knowledge Management in Matrix Multinational Organizations. U: O’Sullivan, K. (ur.), Strategic Knowledge Management in Multinational Organizations (str. 311-322). Hershey, PA: Information Science Reference

Vrdoljak Raguž, I. i Hazdovac, K. (2014). Društveno odgovorno poslovanje i hrvatska gospodarska praksa. Oeconomica Jadertina, 4(1): 40-58.

Young, S. B. (2014). Moralni kapitalizam II. Zagreb: Hrvatsko udruženje menadžera i poduzetnika CROMA. 


\title{
CONSUMERS' PERCEPTION OF CORPORATE SOCIAL RESPONSIBILITY IN FOOD RETAILING IN THE REPUBLIC OF CROATIA
}

\author{
Romana Zlatar-Vulić
}

\begin{abstract}
Modern business environment places many challenges before corporations with regard to accomplishing their defined goals and running a successful business while, at the same time, respecting basic social and moral values, as well as looking after the community's wellbeing. An increasing number of corporations has begun to realize that their business strategies must also incorporate care for social and living environments, as a kind of investment into achieving a more competitive advantage and having a more efficient business, while contributing to the wellbeing of the society as a whole. Successful and reputable corporations no longer base their business solely on attaining maximum profit but their management strategies also incorporate the principles of corporate social responsibility (CSR) on voluntary basis, with the goal to reconcile their business with the needs of the society, as well as to create a high living standard for their interest groups (stakeholders) within and outside of the corporation.

The aim of this paper is to empirically determine whether there are statistically significant correlations between socio-demographic characteristics (sex, age and the level of education) of the respondents and the level of their awareness of the concept of CSR in food retailing. It also examines whether their awareness regarding CSR principles in food retailers affects their decisions to buy their products. The results reveal that there are no statistically significant correlations between sex and age of the consumers and their awareness of CSR. However, there are statistically significant correlations between their level of education and being informed about CSR principles (it is lower in lower educated respondents). There are also no statistically significant differences between age and level of education of consumers and their interest in CSR principles in food retailing, however, there is a correlation with regards to sex (interest is higher among males). Finally, the results reveal that quality is the decisive factor in the process of choosing and buying food products, and that there are no statistically significant differences between sex, age and level of education of consumers with regard to this.
\end{abstract}

Key words: corporation, corporate social responsibility, business strategy, sustainable development

\section{UNTERNEHMERISCHE GESELLSCHAFTSVERANTWORTUNG IM KONTEXT DES KÄUFERVERHALTENS BEIM KAUF VON NAHRUNGSMITTELN IN DER REPUBLIK KROATIEN}

\author{
Romana Zlatar-Vulić
}

\section{Zusammenfassung}

Die zeitgenössische Geschäftstätigkeit stellt die Unternehmen vor zahlreiche Herausforderungen bei der Verwirklichung ihrer gesetzten Ziele und erfolgreichen Resultate, dabei werden grundlegende gesellschaftliche und moralische Werte respektiert und es wird dem Wohle der Gemeinschaft Rechnung getragen. Immer mehr Unternehmen verstehen, dass sie Sorge um Gesellschaft und Umgebung in ihre Geschäftsstrategie einschließen müssen, dies ist eine Art Anlage in den Wettbewerbsvorsprung und ins Erreichen einer effizienten Geschäftstätigkeit des Unternehmens, was zu einer Verbesserung des Wohls der ganzen Gesellschaft beiträgt. Erfolgreiche und angesehene Unternehmen basieren ihre Geschäftstätigkeit nicht mehr ausschließlich auf dem Erzielen eines maximalen Gewinns sondern beachten in ihrer Geschäftsstrategie die Anwendung des Prinzips der Unternehmerischen Gesellschaftsverantwortung (CSR, nach dem englischen Corporate Social 
Responsibility) auffreiwilliger Basis zwecks Angleichung der Geschäftstätigkeit mit den Bedürfnissen der Gesellschaft und Schaffung eines hohen Lebensstandards für Interessengemeinschaften (Akteure) innerhalb und außerhalb des Unternehmens.

Das Ziel dieser Arbeit war es festzustellen, ob eine statistisch relevante Verbindung zwischen Geschlecht, Lebensalter und Bildungsgrad hinsichtlich der Informiertheit der Befragten zu Begriff der CSR besteht, und ob die Informationen darüber, ob das Unternehmen sie durchführt, das Kaufverhalten der Befragten beeinflusst. Die Resultate haben gezeigt, dass es keine statistisch relevante Verbindung zwischen Geschlecht und Lebensalter der Befragten hinsichtlich der CSR besteht. Es wurde jedoch festgestellt, dass der Bildungsgrad die Informiertheit der Befragten über die CSR beeinflusst (weniger Informiertheit bei weniger gebildeten Käufern). Aus der Forschung geht auch hervor, dass es keine statistisch relevante Verbindung zwischen Lebensalter und Bildungsgrad der Befragten hinsichtlich des Interesses der Käufer für die CSR in Nahrungsmittelbetrieben besteht, aber es ist vorhanden hinsichtlich des Geschlechtes (höher bei Männern). Auch wurde festgestellt, dass die Qualität ein entscheidender Faktor im Prozess der Auswahl und des Kaufes von Lebensmitteln ist, aber es besteht kein statistisch bedeutsamer Unterschied nach Geschlecht, Alter und Bildungsgrad bei dieser Frage.

Schlüsselwörter: Unternehmen, unternehmerische Gesellschaftsverantwortung, Geschäftsstrategie, nachhaltige Entwicklung 